\title{
Radical and Incremental Innovation Preferences in Information Technology: An Empirical Study in an Emerging Economy
}

\author{
Tarun K. Sen', Parviz Ghandforoush²
}

\begin{abstract}
Innovation in information technology is a primary driver for growth in developed economies. Research indicates that countries go through three stages in the adoption of innovation strategies: buying innovation through global trade, incremental innovation from other countries by enhancing efficiency, and, at the most developed stage, radically innovating independently for competitive advantage. The first two stages of innovation maturity depend more on cross-border trade than the third stage. In this paper, we find that IT professionals in in an emerging economy such as India believe in radical innovation over incremental innovation (adaptation) as a growth strategy, even though competitive advantage may rest in adaptation. The results of the study report the preference for innovation strategies among IT professionals in India and its implications for other rapidly growing emerging economies.
\end{abstract}

Keywords: IT innovation; globalization and it; adaptation; it in emerging economies.

\footnotetext{
I Professor, Department of Accounting and Information Systems. Pamplin College of Business Virginia Tech Room 3447054 Haycock Road, Falls Church,Va 22043, USA. Phone: 703538 84I7, Fax: 703538 84I5 E-mail: tksen@vt.edu

${ }^{2}$ Corresponding Author. Professor, Department of Business Information Technology. Pamplin College of Business Virginia Tech Room 34I 7054 Haycock Road, Falls Church,Va 22043, USA. Phone: 7035388410 Fax: 703538 8415.E-mail:parviz@vt.edu
} 


\section{Introduction}

The debate about radical innovation and incremental innovation or adaptation has been increasingly pronounced as the world promotes more trade across borders (Banerjee and Cole 20II). As communication improves and international businesses prosper through rapid growth in the IT industry, critical issues related to radical innovation and adaptation of new technologies need to be addressed (Chesbrough et al. 2006). According to Porter (1990) competitiveness of nations goes through three stages of development. In the first stage poorer nations primarily depend upon trade for importing innovations from other countries. In the second stage emerging economies adapt technology and service innovations and make them more efficient through indigenous resources. This is incremental innovation. In the third stage developed nations radically innovate for competitiveness. Emerging economies benefit most by adopting the second stage, i.e. incrementally innovating for competitiveness and growth. In this paper the term adaptation refers to incremental innovation (Marquis 1969) as contrasted to radical innovation.

As is evident from recent economic growth data, that the BRIC (Brazil, Russia, India,China) countries are the fastest growing emerging economies in the world with growth rates often exceeding $8 \%$. Growth strategies for emerging economies should not emulate the strategies of the western world, and make "cheap copies of our worst habits" (Friedman 2007). They should learn from the problems of the developed world and incrementally innovate new technologies that alleviate problems already faced. Keller (2008) observes that the IT led growth in India is not due to radical innovation but rather an extension of the developments in IT in the US.

There is evidence to indicate that multi-national corporations (MNCs) use their subsidiaries for incremental innovation that are prompted by host country knowledge bases that are not accessible to the MNCs in their home country (Phene \& Almeida, 2008). An innovation economy requires a mindset and significant financial investment whose returns are long term (Talke 2007). There is little doubt in people's minds that innovation is important for economic growth. It has also been shown that incremental innovation plays a very important role in innovation diffusion and marketability. There are clear examples to show that fundamental innovators have often not been able to leverage the market as successfully as adaptors (Salomo et al. 2007). Examples abound in the IT, automotive, and pharmaceutical sectors (Castiaux 2007).

Recent studies in international business strategies for emerging economies place a growing emphasis on institutional characteristics that are social, political, and legal (Peng et al. 2008). Innovation strategies for emerging economies are therefore colored by these institutional characteristics and could lead to strategies that are markedly different from those of developed economies (London \& Hart 2004, Meyer 2004, Ramamurti 2004).

A related issue in the area of innovation strategies for IT in emerging economies is intellectual property rights. Prosperous economies attempt to protect innovation through patents while laws related to patents are not as restrictive in emerging economies especially when it is related to fundamental shifts in innovation (Ginarte and Park 1997).

One of the contentious trade issues between the USA and emerging economies like India and China has been intellectual property and patent rights. In the pharmaceutical industry, for instance, patent laws can protect the formulation for a drug for years. Patent laws in India on the contrary only protect a process of drug formulation and not the formulation itself and that too for a period of seven years (Fink 2000). Thus, it has been relatively easy to adapt to new drug formulations that enjoy patent protection in the USA by the Indian pharmaceutical industry by creating a process that manufactures the same formulation using an unpatented process.

Researchers (Ethiraj et al. 2008) have argued that design characteristics like the degree of modularity can have an impact on how likely it is that the product can be copied. These characteristics like modularity are also often embedded in the design of information systems to enhance flexibility and innovation. Sometimes innovators may desire imitations if they expect to profit from it by adding to the product's wider market acceptance.

In order to understand innovation strategies that emerging economies should adopt, we consider it important to understand the perceptions of the primary users of innovation, i.e., the working professional in an emerging economy. This paper focuses on one of these emerging 
economies, India, and assesses the degree of importance given to innovation and adaptation by information technology professionals. We chose the information technology sector as it germinated the seeds of rapid growth in India. The results of this paper lead to a preliminary evaluation of growth strategies adopted by emerging economies. The study does not promote one strategy (radical innovation over incremental innovation or vice versa) over the other.

\section{Stages of Competitive Development of Nations}

Porter's (1990) model for the stages of competitive development of nations clearly demonstrates the need for adaptation or incremental innovation in emerging economies. The drivers for the three stage model for competitive development are factor, investment, and innovation. According to Porter (1990) the factor driven stage prevails primarily through imitation and is applicable to highly undeveloped countries that depend upon innovations from other countries. The investment driven stage applies to nations that add value by providing products and services more efficiently. This is the adaptation economy that is purported to be prevalent in emerging economies. The innovation stage is primarily for developed countries where radical innovation in products and services are the competitive drivers for growth. We adopt Porter's model (Figure I) to illustrate the three stages of international trade driven growth through imitation, adaptation, and innovation. Based on Porter (1990), for emerging economies, it is expected that their competitive advantage lies in adaptation through appropriate limited resource applications.

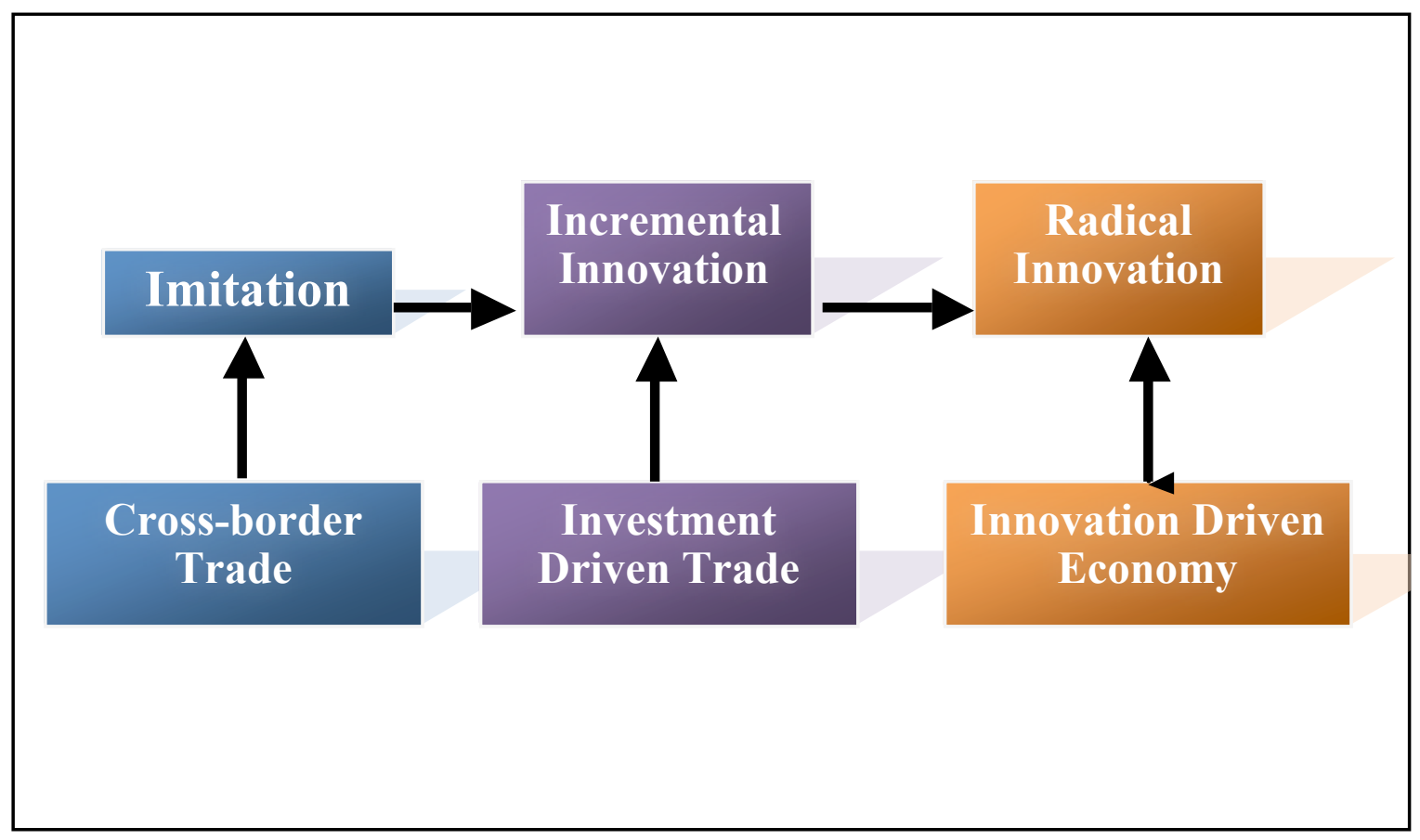

Figure I. Stages of Competitive Development in Information Technology (Adapted from Porter, 1990) 
Before we embark upon the study, a clear distinction between radical innovation and incremental innovation or adaptation needs examination. Innovation is a complex concept and cannot be easily defined and is subject to the reader's interpretation. In order to provide clarity, one needs a classification system for the types of innovations. One classification provided by Marquis (1969) defines innovation using the following terminology: radical, systems, and incremental innovations. Radical innovation represents a new functionality or technology that has not been identified before. It suggests a paradigm shift, like the invention of the wheel, transistor, microprocessor etc. Systems innovation is similar to radical innovation; however it is achieved using a combination of existing technologies to produce a new one that has not been seen before. In this paper, we will use the term radical innovation for both systems and radical innovations. The third type of innovation is called incremental. This type of innovation improves upon existing functionalities by reducing cost, improving efficiency etc. In this paper incremental innovation is referred to as adaptation. Thus adaptation is also a form of innovation however it is not radical or systems innovation. It is clear that whether you adapt or radically innovate, if no value is added in the new functionality there is unlikely to be a differentiated market. Such adaptation of business models for emerging economies, as in the now famous "bottom of the pyramid" model, has long been advocated by researchers like Hammond and Prahalad (2004). The "bottom of the pyramid" model advocates targeting the low income population of emerging economies. Combined with Porter's model, growth strategies of emerging economies would advocate a focus on the early stages of the competitiveness development model (Figure I).

Radical innovation without the ability for others to adapt in a globalized world will clearly impede growth by keeping prices high. Early innovators will always command the highest margins when the product or service is introduced, while adapters will have lower margins due to competitive forces. Leading economies of the world have traditionally been innovators, while poorer countries have primarily been slow adapters. Adaptation is as important for growth as radical innovation; however, the challenge is that adaptation must add value by enhancing the capability of the product or service to different market conditions around the world.

\section{Research Method}

In this study we investigate the prevailing preference for incremental innovation or adaptation over radical innovation due to increased cross-national trade as a result of globalization. Although our study is based on data from a single country, India, the results are of international significance because India has been a clear beneficiary of radical innovations in IT and globalization. According to Tang and van Witteloostuijn (2007), a single country study can be sufficiently generalized if the study involves the impact of "international trade regulations and how they impinge on domestic firms in one country."

This study explores factors that affect radical innovation and adaptation strategies, preference for radical innovation over adaptation and vice versa, and the attitude towards licensing in emerging economies. Data is obtained by interviewing information technology professionals in India, an emerging economy. These professionals were targeted primarily because they are involved in an innovation oriented profession and were expected to have well articulated views towards innovation. Obtaining data primarily from the IT industry provides internal validity at the cost of external validity. A more extensive future study can look at industry as a whole.

It is expected that an emerging market like India would show a significant preference towards incremental innovation or adaptation over radical innovation as described in Porter (1990). This study will examine the validity of Porter's assumption as it relates to the information technology business sector in India. The results of this study will enable us to identify factors that may influence the choice between radical innovation and adaptation. Demographic factors are likely to have an influence on innovation preference, e.g. an individual's fundamental propensity towards innovation is likely to have an influence on innovation preferences.

Clearly India has innovated in many ways; their IT services delivery model is indeed innovative. The Tata Nano is a significant innovation. There are examples of radical innovation in the Indian economy, for example, the identification of the well known Bose-Einstein condensate that has laid some of the foundations of the probabilistic nature of quantum physics. The Jaipur Foot, a prosthetic, is another fundamental innovation that has its origins in India. The Tata Nano and the IT services industry are 
indeed innovations; however, they are adaptive in nature. The Nano uses materials, components, and processes that have radically reduced the cost of building a car. At the heart of the revolution in the IT services industry is communications technology, primarily the internet. Without that revolution, the IT industry in India could not have leveraged the services industry in the global workplace. These adaptive or incremental innovations depend upon other radical innovations that have taken place.

The model shown in Figure 2 shows that propensity to innovate may be motivated by different factors related to an individual's experiences and responsibilities in their profession. Several demographic factors are expected to affect an individual's propensity to innovate or adapt. The factors considered to be most significant in influencing innovation (Castiaux 2007) are the size of the organization, the industry category in which the individual has worked, the position in which the individual has worked in the organization (along with their related salary level). The innate propensity to innovate or adapt is also affected by the prevailing economic environment. A study reported at the World Economic Forum of 2007-08 (Sala-I-Martin et al. 2007) finds that India is ranked fourth in the availability of scientists and engineers. Economic factors will have an impact on the propensity to radically innovate or adapt which leads to an individual's innovation preferences and attitude towards intellectual property rights.

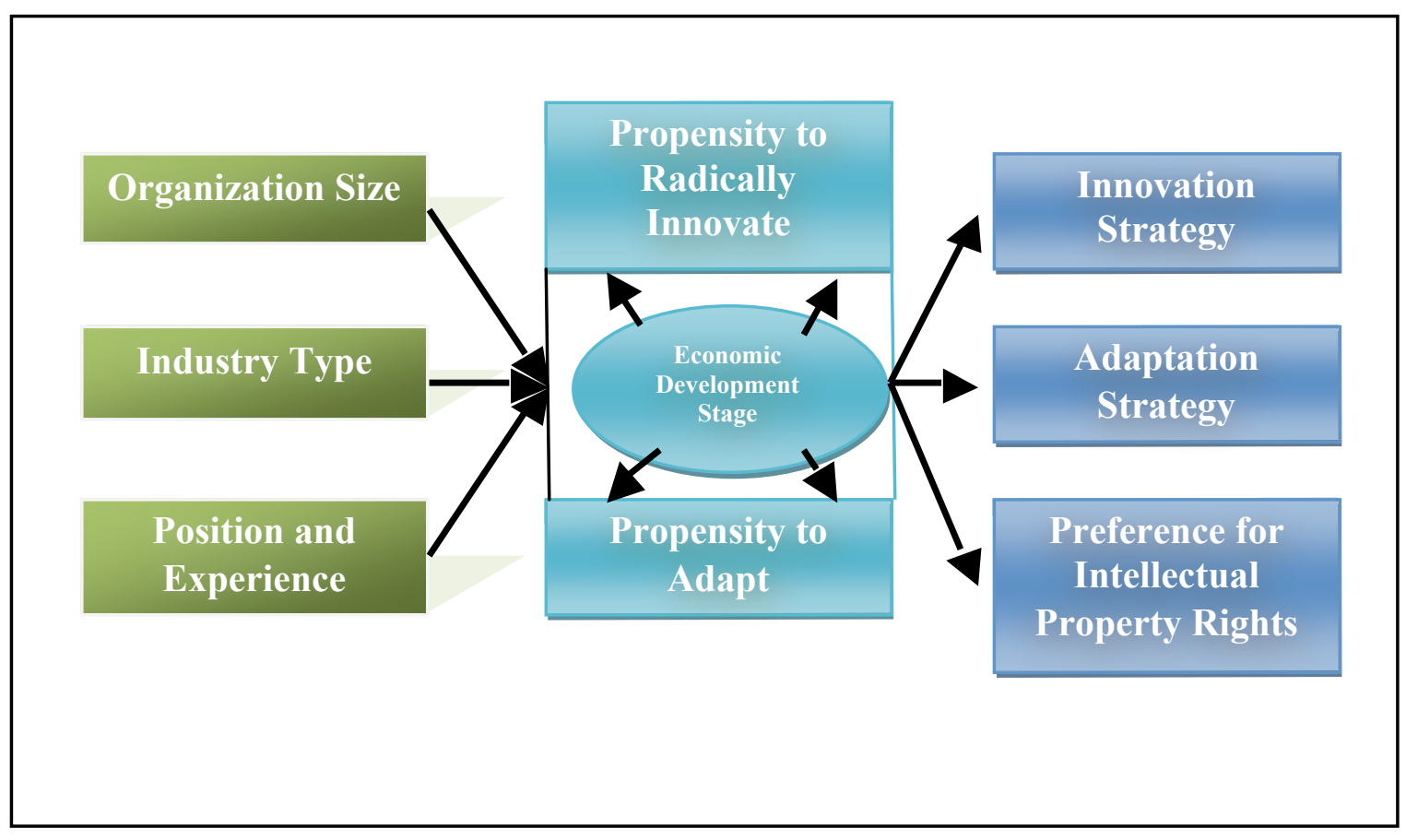

Figure 2. Information Technology Innovation Preference Model 


\section{Data Collection}

One hundred and two professionals in India were interviewed from organizations that were small to very large and were spread across several information technology intensive industry sectors. IT professionals were interviewed by graduate students who were in a Masters of IT program offered by Virginia Tech in Mumbai India. The students were trained in the interview process and were selected on the basis of their work experience in the IT industry prior to joining the masters in IT program. Professionals from India's leading information technology companies including Infosys, Satyam, Tata Consulting Services, Wipro, and MindTree Consulting, among others, were represented in the sample. The sample data consisted of equal number of respondents from each of these corporations. Respondents were given general information regarding the research study and were explained the difference between adaptation and radical innovation. Respondents were asked to fill out a pre-determined questionnaire. Responses from each questionnaire were reviewed for clarity and completeness, and a follow up interview was scheduled to better understand responses given on the questionnaire. This allowed for the opportunity to correct any misunderstandings on the part of respondents in the meaning of questions in the survey and to clearly understand their responses. The organizations selected were not a random sample. Rather, a collection of 102 individuals from companies varying in size from small to large and with extensive information technology knowledge and responsibility willing to participate in the survey were identified and tested.

About $18 \%$ of those interviewed had graduate level college degrees. Except for one, the remaining individuals had undergraduate degrees. Almost $80 \%$ of the professionals interviewed either worked for IT organizations or had IT related jobs. Sixty four percent of the respondents were IT consultants, $17 \%$ were analysts, $9 \%$ were managers, and another $9 \%$ were senior level managers. Seventy four percent of the respondents were male. The salary levels of the participants were consistent with their age and job functions that they performed.

The data was analyzed using the generalized linear model (GLM) statistical procedure. GLM is a robust regression model that is suitable for both categorical and continuous variables. GLM reports the F-statistic and its associated $\mathrm{p}$-value, using which the hypotheses are tested for statistical significance. The test results are reported in Table I. Some of the hypotheses required a test for differences in means. In such cases, a two sample t-test for means was used. These results are reported in Table 2.

\section{Hypotheses and Results}

To study the innovation preferences of IT professionals in an emerging economy like India, the research questions were formulated as hypotheses (Herrmann et al. 2007).

Hypothesis I. There will be a significant difference between the propensity to radically innovate and the propensity to adapt or incrementally innovate.

The first hypothesis tested was to see whether IT professionals had a preference for radical innovation or adaptation as a growth strategy. A paired t-test was performed (Table 2) to see if there was a significant difference. The difference between the two means is significant ( $P$ value .004). On a scale of one to seven, where seven indicates strongest preference, the mean for radical innovation importance is 6.255 , whereas the mean for adaptation is 5.85. Contrary to our expectations and Porter's (1990) model, respondents consistently had a stronger preference for radical innovation than adaptation.

Hypothesis I was followed up to see if the respondents believed whether innovation or adaptation will lead to higher economic prosperity.

Hypothesis 2. Radical innovation will result in higher economic prosperity than adaptation.

A means test was conducted to see if there was a significant difference in the belief that radical innovation was better than adaptation for economic prosperity. The difference was observed to be highly significant ( $p$ value .000). On a scale of one to seven (where seven indicated a stronger belief) the mean for innovation as a strong contributor to economic prosperity was 5.8I whereas the mean for adaptation was 4.95. This result is again contrary to our model and Porter's (1990) strategy of adaptation for emerging economies. 
We then looked at factors like organizational characteristics that may cause this strong preference for innovation over adaptation among IT professionals in India.

Hypothesis 3. Organization size should have an impact on the propensity to radically innovate.

Hypothesis 3, the impact of organization size (in terms of revenue) on the propensity to radically innovate was significant ( $p$ value .007). Company size was determined on a 5 point scale based on revenue. The means indicate that mid-sized companies had the highest preference for radical innovation. Organization size, as determined by the number of employees, also had a significant impact on the perceived importance of innovation ( $p$ value .023). The smaller companies had the most significant impact, while larger companies had less of an influence. These results indicate that mid to smaller organizations have a stronger preference for radical innovation.

\begin{tabular}{|l|c|c|c|c|}
\hline Hypotheses & Independent Variable & Dependent Variable & F Stat. & P value \\
\hline Hypothesis 3 & $\begin{array}{c}\text { Orgn. Size (Revenue) } \\
\text { Orgn. Size (No. of Emps) }\end{array}$ & $\begin{array}{c}\text { Innov. Importance } \\
\text { Innov. Importance }\end{array}$ & $\begin{array}{c}3.77 \\
3.34\end{array}$ & .007 \\
\hline Hypothesis 4 & Orgn. Type & Innov. Importance & 3.10 & .009 \\
\hline Hypothesis 5 & Orgn. Level & Innov. Importance & 2.28 & .068 \\
\hline Hypothesis 6 & Innovation Importance & Innov. Investment & 4.25 & .003 \\
\hline Hypothesis 7a & Adaptation Importance & Research Adapt. & 2.55 & .044 \\
\hline Hypothesis 7b & Adaptation Importance & Research Adapt. & .40 & .806 \\
& & University & & .000 \\
\hline Hypothesis 8 & Innovation Importance & Adapt. Harmful & 5.94 & .602 \\
\hline Hypothesis 9 & Innovation Importance & Patent laws & .69 & .087 \\
\hline Hypothesis 9' & Adaptation Importance & Patent Laws Health & 2.10 & \\
\hline
\end{tabular}

Table I. Results for Generalized Linear Models

We also tested to see if organization type has an impact on the choice of radical innovation vs. adaptation.

Hypothesis 4. Organization type should have an impact on the propensity to radically innovate.

The organization type, as determined by the nature of the work the respondent performed, had a very strong impact on innovation ( $p$ value .009). Those involved in high technology functions had a stronger preference for radical innovation. Those involved in other functions that did not have a strong need for technology had less of an impact on the propensity to innovate.
Hypothesis 5. Organizational level will have an impact on the propensity to radically innovate.

It is expected that the higher up an individual is in the organization, the more likely she will be favorable towards innovation. Maturity in an organization and higher accountability should lead to a stronger propensity to innovate. In emerging economies the propensity to innovate is further characterized by the type of innovation that the individual is more likely to favor.

Hypothesis 5, the impact of organizational level on radical innovation was supported but only at a higher level of significance ( $p$ value .068). Respondents who had 
management responsibilities had a stronger preference for innovation.

The results indicate that organizational characteristics have an impact on innovation preference. It is quite possible that the strong emphasis on innovation was primarily due to the industry type and organizations chosen.

We then explored where IT professional thought that the country should invest for growth, radical innovation or adaptation.

Hypothesis 6 . The propensity to innovate should lead to a stronger preference for investments in radical innovation than investments in adaptation of information technology.

Hypothesis 6 focuses on the respondents' preference for innovation over adaptation investment and its relationship to their propensity to innovate. As expected, this relationship is highly significant ( $p$ value .003). This is not surprising since we would expect that those who considered innovation to be important would likely want more investment in innovation. However, this viewpoint would be consistent with those that would be observed in developed economies.

Hypothesis 7. The propensity to adapt should lead to a stronger preference for adaptation research in IT in universities and corporations.

Hypotheses 7 looked at the question of the relevance of adaptation research in emerging economies and where they should be carried out, corporations or universities. The hypothesis was split into two, 7a for corporations and $7 \mathrm{~b}$ for universities. The results related to Hypothesis $7 \mathrm{a}$, the relationship between adaptation importance and adaptation research investment in corporations, was significant ( $p$ value .044). However, Hypothesis 7b, the relationship between adaptation importance and investment in adaptation research in universities was not significant ( $p$ value 0.806 ). This implies that respondents preferred that adaptation research be carried out in corporations and not in universities. The implication is that universities should carry out more fundamental and radical research. This is contrary to our primary proposition that emerging economies should focus on adaptation research and not on radical innovation, as it may not be the best use of resources. This finding is not surprising, as there is little evidence to believe that emerging economies are adopting research strategies in IT that are significantly different from those carried out in developed economies.

Hypothesis 8 . The propensity to radically innovate should consider adaptation to be harmful to an emerging economy.

Hypothesis 8 looked at the issue of innovation preference and its impact on adaptation preference. The results indicate that there is a strong relationship between the preference for innovation and the perceived harmful effects of adaptation. Those who considered radical innovation to be important for economic growth, considered a focus on adaptation to be harmful for economic growth ( $P$ value.000). A follow up test found that those who considered adaptation to be important had no significant effect on the perception that adaptation can be harmful to economic growth ( $p$ value 0.622 ). Thus, a strong preference for radical innovation could lead to policies that may look down upon the very concept of adaptation or incremental innovation.

Hypothesis 9. Stronger preference for radical innovation should lead to a stronger preference for patent laws.

Hypothesis 9 deals with the impact of innovation preference on attitudes towards patent laws. Contrary to expectations there is no significant impact of innovation preference to the degree to which respondents thought that patent protection was important ( $p$ value .602). However, there was a significant impact of adaptation importance on patent protection for goods and services for social welfare, e.g. pharmaceutical industries ( $p$ value .087) at a confidence level of .10. Interestingly, the means indicated that the stronger the preference for adaptation the weaker was the preference for patent laws for pharmaceuticals. This is expected given the current mood for patent laws for pharmaceuticals in emerging economies. Also a two sample t-test for means (Table 2 ) indicates that respondents felt differently about patent protection in IT and patent protection in the health industry ( $p$ value .014). The means indicate a stronger preference for patent protection in IT than patent protection in the health and pharmaceutical industry. On a scale of one to seven, where seven indicated a strong preference for patent protection, the mean for patent protection in general was 5.265 whereas the mean for patent protection for the health industry was 4.627 . 


\begin{tabular}{|c|c|c|c|}
\hline Hypotheses & Variables & t - Statistic & $\mathbf{p}$ Value \\
\hline Hypothesis 1 & Innovation Importance - Adaptation Importance & 2.88 & .004 \\
\hline Hypothesis 2 & Innovation Prosperity - Adaptation Prosperity & 5.02 & .000 \\
\hline Hypothesis 9' & Patent Laws - Patent Laws Health & 2.47 & .014 \\
\hline
\end{tabular}

Table 2. Results for Two Sample t tests

\section{Analysis of Results}

One of the critical elements of this study is to observe preferences for adaptation (or incremental innovation) and radical innovation among IT professionals in an emerging economy such as India. Porter's (1990) model for innovation in emerging economies posits that adaptation of technology is more critical than radical innovation in emerging economies. Our results are surprising in that we find that the general perception towards radical innovation in IT in India do not seem to be any different than what would be perceived in developed economies. Among IT professionals, there was a consistent belief that radical innovation is more desirable than adaptation. This is contrary to what one would expect in India. Barma (2005) articulates clearly the role of adaptation in India and its successes.

IT professionals consider radical innovation to be more important for the economy than adaptation. This emphasis if it actually results in significant investments in radical innovation research may be counterproductive for an emerging economy like India, where most of the growth is related to how Indian corporations have adapted to radical innovation carried out in developed countries. Indian companies have successfully adapted. Examples abound in adaptation of wireless technologies, e.g. the cell phone industry, development of new business processes for streamlining outsourcing, e.g. managed services, medical tourism, micro financing, and numerous other areas. Appropriately directed research can identify other areas of incremental innovation that will continue to spur rapid growth. Barma (2005) strongly advocates the closer collaboration of universities and private firms in doing research that would make the adoption of new technologies more efficient in India, providing India stronger competitive advantage. Consistent with Porter (1990), Barma (2005) advocates research "in more basic frontier-technology ... at a later stage of economic development."

The Indian IT industry has reached a maturity level, probably hastened by the global financial meltdown. Clearly the initial growth in the outsourcing services area was fueled by the booming economy over most of the last two decades. The current sustained growth in the IT services area in India is indicative of innovations that are working. The maturity of the IT industry provides significant resources for radical innovation. Opportunities exist in micro-financing, mobile payments, mobile ads, software as a service (SaaS), and other areas suitable for emerging markets with large populations. There is clear evidence that the industry is moving towards adopting these innovation avenues and there is peaked interest from the venture capital community.

A preference for radical innovation was closely associated with a perception that adaptation is harmful for the Indian economy. This may be a cause for concern as some of the most successful firms in the world adapt very successfully. An attitudinal change may be brought about by emphasis on adaptation and bringing some of its critical aspects through research into the education curriculum. Talke (2007) describes the mindset of innovating firms and shows what firms can expect when they attempt to move from one stage of innovation to the next. For example, higher acceptance of adaptation based strategies can be nourished by newer patent transfer models. Chesbrough (2007) describes a secondary model for radical innovation based on Arora et al's (200I) research on intermediate markets. There is a growing propensity to transfer patents to secondary markets for reasons related to resources or efficiency, among others. The secondary market for innovations becomes increasingly important due to globalization as original patent holders transfer patents to businesses in other countries for growth opportunities ( 
Davis 2008). This makes adaptation a lucrative business opportunity for emerging economies and can result in a weaker preference for patent laws as intellectual property is traded more freely in open markets.

Although intellectual property rights were considered important by IT professionals in India, there was no observed relationship between a stronger preference for innovation and a correspondingly stronger preference for intellectual property rights through patent laws. There was a markedly reduced preference for patent laws in industries related to social welfare like health and pharmaceutical industries. This was expected given the sentiments related to prices for health care products and services in developing economies.

Globalization may be challenging the very basis of innovation strategy which is geared towards protection through patents, competitive advantage, barrier to entry and other traditional business strategies based on Porter's (1985) work on competitive advantage. Chesbrough and Appleyard (2007) challenge this strategy introducing the concept of open innovation as is being demonstrated by the new internet technologies like Myspace, YouTube, Facebook, Yearbook, etc, where the barriers to entry are very little and the firm creates value through openness. Value creation in globalization can be attributed significantly to openness (Friedman 2005). It is likely that IT innovation in a globalized world is going to move in this direction. There is already growing evidence in the pharmaceutical industry that increased patenting is stifling the introduction of new drugs as this may be dependent on the use of numerous other patented molecules and organisms making the effort financially infeasible. Cloud computing in the IT industry is also moving innovation towards adaptation with a shift away from patented technologies.

\section{Future Research}

The results of this study are limited because of the restricted sample pertaining to one emerging economy, India. This was not a comparative study between developed and emerging economies. Results from such a study would have provided a better grasp of the differences that may exist in innovation strategies related to growth. Past research indicates that developed and emerging economies produce different returns on IT investments (Dewan and Kraemer 2000). An empirical investigation with economic data of the impact of adaptation vs. innovation from multiple countries would lead to more conclusive results. Future research could also be aimed at investigating why there is a strong emphasis on radical innovation in India whereas it would seem that adaptation would be a more productive strategy at this stage of economic development. It would be interesting to investigate the proportion of research funds invested in radical innovation or fundamental research as compared to adaptation research in India.

\section{References}

ARORA, A., Fosfuri, A., Gambardella, A. (200I). Markets for Technology. MIT Press, Cambridge, MA.

BANERJEE, P., Cole, R. (20II). Globally radical technologies and locally radical technologies: the role of audiences in the construction of innovative impact in biotechnology. Transactions on Engineering Management, 58(2), 262-274.

BARMA, N. (2005). The emerging economies in the digital era: market places, market players, and market makers. BRIE Working Paper 167, University of California, Berkeley, CA.

BOWER, J., Julian, S. (2006). Social and intellectual capital formation in leading Indian pharmaceutical companies. International Journal of Innovation Management, 10(4), 407-423.

BROWN, C., Linden, G. (2006). Semi-conductor engineers in a global economy. National Academy of Engineering Workshop on the Off-shoring of Engineering: facts, myths, unknowns, and implications, Washington DC.

CASTIAUX, A. (2007). Radical innovation in established organizations: being a knowledge predator. Journal of Engineering \& Technology Management, 24(I-2), 36-52.

CHESBROUGH, H.W. (2007). The market for innovation: implications for corporate strategy. California Management Review, 49(3), 45-66.

CHESBROUGH, H.W., Ahern, S., Finn, M., Guerraz, S. (2006). Business models for technology in the developing world: the role of non-governmental organizations. California Management Review, 48(3), 48-6I. 
CHESBROUGH, H.W., Appleyard, N.M. (2007). Open innovation and strategy. California Management Review, 50(I), 57-93.

DAMANPOUR, F. (1992). Organization size and innovation. Organization Studies, 13(3), 375-402.

DAVIS, L. (2008). Licensing strategies for the new intellectual property vendors. California Management Review, 5(2), 6-30.

DESHPANDE, R., Farley, J. U., Bowman, D. (2004). Tigers, dragons, and others: profiling high performance in Asian firms. Journal of International Marketing, 12(3), 5-29.

DEWAN, S., Kraemer, K. (2000). Information technology and productivity: evidence from country-level data. Management Science, 46(2), 548-562.

ETHIRAJ, S.K., Levinthal, D., Roy, R. (2008). The dual role of modularity: innovation and imitation. Management Science, 54(5), 939-955.

FINK, C. (2000). How stronger patent protection in India might affect the behavior of transnational pharmaceutical industries. World Bank Policy Research Working Paper No. 2352. Washington, D.C.

FRIEDMAN, T.L. (2005). The World Is Flat. Farrar, Strauss, and Giroux. New York.

GINARTE, J.C., Park, W.G. (1997). Determinants of patent rights: a cross national study. Research Policy, 96, 283-30I.

HAMMOND, A.L., Prahalad, C.K. (2004). Selling to the poor. Foreign Policy, 142 (May/June), 30-37.

HERRMANN, A., Gassmann, O., Eisert, U. (2007). An empirical study of the antecedents for radical product innovation and capabilities for transformation. Journal of Engineering \& Technology Management, 24(I-2), 92-I20.

KELLER, K.H. (2008). From here to there in information technology: the complexities of innovation. American Behavioral Scientist, 52(I), 97-I06.
KHAVUL, S. B., Garry, D., Zheng, C., Eric, W. (2007). Learning during and after internationalization by entrepreneurial firms from emerging economies. Academy of Management Proceedings, I-6.

LONDON, T. Hart, S.L. (2004). Reinventing strategies for emerging markets: beyond the transnational model. Journal of International Business Studies, 35(5), 350 -370.

MACHER, J. T., Mowery, D.C., Di Minin, A. (2007). The 'non-globalization' of innovation in the semi-conductor industry. California Management Review, 50(I), 217-242.

MARQUIS, D. (1969). The anatomy of successful innovations. Innovation, I, 35-48.

MEYER, K. E. (2005). Perspectives on multinational enterprises in emerging economies. Journal of International Business Studies, 35(4), 259-276.

PENG, M.W., Wang, D.Y.L., Jiang, Y. (2008). An institutionbased view of international business strategy: a focus on emerging economies. Journal of International Business Studies, 39(5), 920-936.

PHENE, A., Almeida, P. (2008). Innovation in multinational subsidiaries: the role of knowledge assimilation and subsidiary capabilities. Journal of International Business Studies, 39(5), 901-919.

PORTER, M.E. (1985). Competitive Advantage. Free Press. New York.

PORTER, M.E. (1990). The Competitive Advantage of Nations. Free Press. New York.

PORTER, M.E., Ketels, C., Delgado, M. (2007). The Microeconomic Foundation of Prosperity: findings from the business competitive index. The Global Competitiveness Report, 2007 World Economic Forum.

RAMAMURTI, R. (2004). Developing countries and MNEs: extending and enriching the research agenda. Journal of International Business Studies, 35(4), 277-283.

SALA-I-MARTIN, X., Blanke, J., Hanouz, M.D., Geiger, T., Mia, I., Paua, F. (2007). The Global Competitiveness Index: Measuring the Productive Potential of Nations. The Global Competitiveness Report, 2007 World Economic Forum. 
SALOMO, S., Gemunden, H. G., Leifer, R. (2007). Research on corporate radical innovation systems- a dynamic capabilities perspective: an introduction. Journal of Engineering \& Technology Management, 24(I-2), I- 10.

SHARMA, B. R. (1987). Not by Bread Alone: A Study of Organizational Climate and Employer-Employee Relations in India. Shri Ram Center for Industrial Relations and Human Resources. New Delhi.

TALKE, K. (2007). Corporate mindset of innovating firms: influences on new product performance. Journal of Engineering \& Technology Management, 24(I-2), 76-9I.

TREECE, D.J. (1997). Firm organization, industrial structure, and technological innovation. Journal of Behavior and Organization, 31, 193-224. 